\title{
Incubation Methods for Forecasting the Occurrence and Development of Lophodermium seditiosum Minter, Staley \& Millar on Pine
}

\author{
Snezana Rajkovic, Miroslava Markovic and Ljubinko Rakonjac
}

Additional information is available at the end of the chapter

http://dx.doi.org/10.5772/51233

\section{Introduction}

Forest nurseries in Serbia are used to produce seedlings for afforestation, plantation establishment, reclamation of degraded forests and scrub, eroded terrain, barren and therefore it is important their proper growing and protection. Based on the review of nursery production, the data collected in $2011^{\text {th }}$, Serbia's state and private sectors, for the afforestation of the total produced 2, 238.798 seedlings of black pine (Pinus nigra) and 1, 311.160 seedlings of Scots pine (Pinus silvestris), aged 1 to 3 years. Of these, container seedlings $P$. nigra produced a total of $698790,1,422.938$ classical pieces, and "educated" seedlings is 126000 pieces. Seedlings of $P$. silvestris are produced in smaller amounts twice, so that the total of 498570 seedlings of container, in a classic production is 812590 pieces.

Pine seedlings are produced in Serbia under the Nature Conservation Movement Svrljig and Surdulica, then "Erosion" of Nis and the private sector (1 site in Sjenica), but to a lesser extent, so that all of the above locations outside the system "Srbijasume" in 2011 . total production amounts of black pine are 326000 , white 30, 000 seedlings aged 1 to 3 years.

In a larger scale, pine seedlings are produced in nine forest management within the public company "Srbijasume" (Uzice, FC, Kraljevo, Krusevac, Despotovac, Pirot, Leskovac, Boljevac and Prijepolje). The greatest production of pine seedlings in the forest management Pirot, which in the past 2011th has had production of 637760 seedlings of red pine and white pine seedlings 457 500. Woodlands Pirot is a modernized production plant conifer seedlings and is scheduled to be (when the system is a spy) and produces up to 4 million seedlings per year, which would fully satisfy the domestic market and allow export to Bulgaria, Greece, Macedonia and other countries. 
Development of nursery production in neighboring countries, for example. Croatia is linked to the beginnings of reforestation karst. The first nursery for the production of forest trees was established in 1879. in Sv. Michael in Senja. Annual capacity was 1.8 to 2 million seedlings. They were mainly produced by pine trees and some sawmills. Shortly after that were built other nurseries, for example. Chestnut nursery (in Senj prefer), Podbadanj (Crikvenica), etc.. Some of them are still active (Podbadanj). Until the end of World War II forest seedlings were produced in temporary forest nurseries, which are mostly done manually. Most were produced by conifers. Only in karst areas were produced seedlings covered with roots. The largest number of existing nursery was founded in the sixties of the 20th century. They introduced modern production technology. Great attention is paid to the origin and quality of seeds, soil fertility and control safeguards.

According to figures presented Zgela [89], Croatia is the production of pine seedlings in the period since 1991. to 1998. amounted to an average of 253000 pieces. Planned production of pine seedlings in the period since 1999. to 2003. was an average of 205000 pieces.

In Bosnia, according to the "Center for Seed - nursery production" in Doboj, the production of conifer seedlings is conducted on an area of 9 ha, of which 6 related to conifers nursery a 3 ha in seminary. The production of conifer seedlings pine accounts for $25 \%$ or 2.87 million units, of which the system are not about 145, 000 pieces of plants, which are located in nursery. Production of white pine is about 1, 500, 000 pieces. White Pine also has the most important production in seminary as well as pine, because it is distributed to the field as a two-year seedlings, and less educated as a seedling. The highest production of shortleaf pine seedlings occurred prior to 1987 with at least 2 million seedlings being produced annually. Today less than half a million seedlings are produced at the nursery. Before 1990 most of the seedlings were delivered to the Mark Twain National Forest, but now it is a minor player in artificial regeneration of shortleaf pine. Trends in seed distributed for direct seeding followed those of seedling production [90].

Seed production in natural plant populations vary widely from year-to-year in response to weather variables, insects and diseases, and internal cycles within the plants themselves. Over a 20-year period, for example, forests composed of Pinus taeda and Pinus echinata produced from 0 to nearly 5 million sound pine seeds per hectare [91]. Over this period, there were six bumper seeds, five poor seeds crops, and nine good seed crops, when evaluated in regard to producing adequate seedlings for natural forest reproduction.

Occurrence of the needle cast disease and the disease agent (historically: Lophodermium pinastri) on the territory of Serbia was examinated and documented by the mycologists [6, 7]. Today we know, that: 1) Lophodermium needle cast epidemics occur in Serbia almost regularly, but not precisely after definite intervals, and 2) needle cast epidemics are much more frequent in forest nurseries than in plantations, sometimes so frequent that the successive epidemics can not be distinguished from each other.

Species from the genus Lophodermium Chevall. (Kingdom: Fungi, Division: Ascomycota, Subdivision: Pezizomycotina, Class: Leotiomycetes, Order: Rhytismatales, Family: 
Rhytismataceae, Genus: Lophodermium) have the anamorphic stage Leptostroma Fr.:Fr. (Deuteromycota, Coleomycetes, Sphaeropsidales), the infectious role of which is unknown $[1,2]$. The genus contains 145 species and has a global distribution. The genus infects many different plant families but with a notable concentration in the family Pinaceae. Some are economically important plant pathogens, such as those that cause needlecast disease in European Black Pine, Scots Pine and Red Pine in forestry and christmas tree plantations. In these species, notably L. pinastri and L. seditiosum, the fungal spores disperse and infect the pine needles in late summer, which turn brown by the following spring and then fall off. It is the most dangerous and the most harmful pathogenic fungus in nurseries and young crops, which causes redness and dispersal of pine needles. It occurs on the needles from the current vegetation of a large number of Pinus species [3, 4]. In Serbia, especially susceptible are Pinus sylvestris and Pinus nigra, although P. sylvestris is slightly more sensitive [5].

It is almost impossible to produce healthy seedlings of good quality without control of Lophodermium spp.[7]. Protection should be done during the critical period of infection, and only chemical measures are effective. However, outbreaks of this disease continue to occur periodically when control measures are not applied and where climatic conditions are conducive to disease development and pathogen spread. The fungus can also have a longer life cycle lasting for several years $[8,9,10,11]$.

Timing of spray applications is critical. Infected plantings should be sprayed three times, beginning in late July, in mid-August, and again in mid-September. In severely infected plantings an additional spray may be required in late September or early October, especially if wet weather prevails during this period. Conversely, in lightly infected plantings, the initial, late July spray may be omitted if dry weather prevails at this time. Studies show September to be the key month in which maximum spore release and infection occur.

When application of chemical disease control is economically feasible, as in the case of Christmas trees or forest nursery stock, the pest manager must understand the life cycle of the disease to be controlled. For many diseases, only one short window of control may be available in a calendar year, or the control spray may have to be applied preventively before any signsor symptoms of disease are present. Chemical control measures must be applied when infection is most likely to occur or it will be a waste of time, effort and money. Undersanding the life cicle of disease organism enables to make a proper and timely management decisions.

It is known that the occurrence and development of parasites in special area is largely affected by meteorological factors (temperature, humidity, precipitation, etc.). In addition, to undrestand the disease it is important to monitoring phenological phases through which the plant passes during the growing season, especially the "critical stage" of development during which the plant is vulnerable to attack parasites. In addition to these and many other factors (sources and amounts of inoculum, plant resistance, cultural practices applied) affect the emergence and spread of harmful organisms. Study of all these factors, as well as using appropriate forecasting model, it is possible to predict the occurrence of pathogens in a specific location and signal the optimal timing of pesticide applications, ie. promptly notify the producers on the implementation of these measures. 
Thus, obtaining a high-quality information in a short period of time, and appropriate professional advice about the time of application, the required dose and choice of products, farmers can save time, reduce losses and increase production yield and quality of its products.

Forecast of harmful organisms is its contribution to the rational use of pesticides and is increasingly gaining in importance. As crop production affected the emergence of different groups of harmful organisms (fungi, bacteria, insects, weeds), which differ in their nature, biology and way of causing damage to the area and share forecasts and develops in accordance with the area to which it relates.

Forecast of harmful organisms is a complex process, the quality of the work requires continuous and thorough implementation of all necessary procedures. A very important role during this process belongs to the monitoring of meteorological conditions in the crop or plantation, necessary for the emergence and growth of harmful organisms. The rapid technological advances in this field of meteorology has enabled the introduction of more modern and easier monitoring devices required meteorological elements.

When it comes to diseases by fungi nature, among the first instruments that were used for these purposes were different thermohygrograph production, which recorded data on the length of wetting rate, relative humidity and air temperature. Today, the prognosis of the disease using automatic weather stations whose work supports various software: $\mu$ Metos (PESSL instruments-Austria), WatchDog (Spectrum Technologies, Inc.-USA), BAHUS (Faculty of Agriculture - Novi Sad) and others. This way is much easier to monitor the conditions of infection in orchards and crops, and created the ability to view a large number of locations depending on the number of cells, which allows for easier monitoring procedure and prognosis of the disease in a large area, making forecasts gets much broader dimension. Thanks to all of the above, achieved significant progress in setting deadlines for the treatment plants and the rational use of pesticides.

The incubation method is the most versatile because it follows the development of parasites, hosts and climatic conditions. As such it is necessary organization of the plant protection service. They also predict the use of fungicides to protect pine seedlings from pathogen $L$. seditiosum at the end of the incubation period. In cases where conditions for realization of infection are more frequent and shorter, the treatment should comprise block use of systemic fungicides, while in cases of less frequent infections and longer incubation periods it is possible to use non-systemic fungicides whose persistence is shorter. By combining the application of fungicides from different chemical groups in this way we avoid the possibility of pathogen resistance to some active ingredients. Treatment with the appropriate fungicide, in terms which we were identified on the basis of calculation by methods of incubation, ensures reduction of the inoculation potential during the following year, which consequently scales down the infection of pine seedlings with this pathogen.

To facilitate the production of healthy and quality seedlings, it is necessary to use appropriate phytosanitary measures with the use of appropriate pesticides. I n Serbia there are still not in full use of legislation which includes all allowed products to protect seedlings 
in nurseries. The certification of forest products is in progress and many are discharged from service, and for which no adequate and field tested replacement. So often in nursery production in Serbia in recent years using insufficiently tested means, or which have shown efficacy in other climates, and have a certificate in relation to our weather.

Therefore, this study should complement and demonstrate the practical use of the fungisides are effective in Serbia, and that without being toxic and the fungicides approved for use. In addition, given that the same is climate different area each year (weather conditions change from year to year, which is particularly acute in recent years, because there are large fluctuations and climate change), models are essential for the prognosis of the disease each year, which also gives the study. Model predictions of some infectious diseases occur in a specific time period each year, the timely preparation of appropriate means to protect effectively to prevent disease and rehabilitation centers in the beginning of infection, before the advent epiphytotia, which would result in a greater amount of healthy trees with a minimum expenditure of resources.

On the basis of previous positive experiences of colleagues scientists from other fields, we tried to apply their experience and to pathogens which will induce diseases in forest plantations. In the field of forestry is limited use of pesticides because of the introduction of FSC policies, generally there are no registered products for the prevention of pathogens in the field of forestry, techniques and the application is poorly developed. We wanted to give our contribution in the first implementations of forecasts from pathogens in foresty according to models that are already used in agriculture. Further research should lead to registration of fungicides for this purpose in the territory of the Republic of Serbia in line with the FSC and the forestry policy, and to study the possibility resistance of fungus to recommended active ingradients since the use of fungicides were for several years undocumented.

\section{Lophodermium needle cast}

\subsection{Biology of the pathogen}

Lophodermium is a genus of Ascomycete fungi that contains both needlecast pathogens and hostspecific endophytes of conifers [33, 34]. Although Minter et al [3] recognised at least four species of Lophodermium which can infect pine needles, only L. seditiosum Minter, Staley \& Millar is considered to be pathogenic [4, 32].

The disease has previously been considered to be caused by Lophodermium pinastri (Schard. ex Hook) Chev. [48], and in older reports, i.e. Costonis [49], the disease has been attributed to this fungus. Two biotypes of L. pinasri, differing in their pathogenicity and morphology, were recognised on Scots pine both in the plantation and in the nursery in Scotland [50]. Form A produced apothecia and black diaphragms on completely brown needles in the litter. In contrast, form B produced larger apothecia without diaphragms on the brown part of one-year-old needles whilst they were still attached to the tree [50]. Later Minter et al [3] showed that there are at least four Lophodermium species which can infect pine needles, and 
described Millar and Watson's form B as a new species L. seditiosum Minter, Staley \& Millar. Although Kurkela [32] did not test the pathogenicity of L. seditiosum, which was the only Lophodermium species isolated from newly browned needles, he concluded that this fungus was the cause of needle cast epidemic of Scots pine in 1975 in Finland. Later inoculations made on Scots pine seedlings confirmed the pathogenicity of L. seditiosum [30,4].

First symptoms of the disease may be visible on pines in September - October as small yellow to brown spots on needles [12, 30,4]. Later, 5 months after inoculation, needles turned brown and died, but the death and shedding of needles did not kill the plants although the new shoots were visibly weakened $[4,31,32,56]$. Owing to the loss of healthy foliage, tree growth and quality were lower in outplanted infected trees than in healthy ones [51]. L. seditiosum was found to be active in seedlings 1 year after planting out [51]. In Finland diseased seedlings have occasionally been planted in the forest because in early spring, just after snow melt, diseased seedlings may still be green. The weakened seedlings have not tolerated the planting stress and have died [44]. L. seditiosum has been shown to infect green primary and secondary needles and only occasionally 2- or 3-year-old needles [52].

Ascocarps of L. seditiosum mature on fallen needles [35] and begin to release ascospores in late summer and peak between September and October in Europe [36, 37] and North America [38]. L. seditiosum preferentially infects green primary and secondary first-year needles [39] via ascospores [40, 41,39]. The occurrence of apothecia was found to be highest on younger primary needles and on 1-year-old secondary needles [41]. According to Kurkela [32], the abundance of L. seditiosum must vary considerably from year to year in Finland. The persistent populations of the fungus seem to be very low and ascospores may arrive from Central Europe or from Estonia where needlecast has proved to be more persistent [57]. Severe epidemics occur only when the weather conditions are suitable for the pathogen [32].

Germinating ascospores form germ tubes ending in melanized, appressorium-like structures $[30,53]$ that penetrate the cuticle and epidermis [42]. The yellow margin of the lesion is caused by starch-free cells in the mesophyll and these cells were externally shown to form the yellow margin of the lesion [30]. Furthermore, the amount of chlorophyll and carotenoid pigments in infected needles is 1.2-3.8 and 1.3-2.4 times lower than in healthy ones, respectively [43]. Seedlings infected with $L$. seditiosum may be undetected as they can appear healthy when planted in the early spring. Minter and Millar [54] compared reports of the ascospore dispersal period, and concluded that different workers have trapped spores of different Lophodermium species. The dispersal of ascospores of L. seditiosum was been shown to start in June and reach its peak between September and October in Sweden [55], Estonia [36], Yugoslavia [37], Germany [10] and the USA [38]. High precipitation during late summer and fall creates conditions favourable for infection [32, 30].

Typically, infected seedlings do not survive planting stress [44] and so there is a need to identify latent infections in material stored below $0^{\circ} \mathrm{C}$ prior to planting. Stenström and Ihrmark [45] have developed species-specific PCR primers which detect also latent 
infections of L. seditiosum. In Finland, needlecast caused by M. laricis has mainly been a problem in Siberian larch during their second growing season [46]. Lophodermium needlecast was among the first diseases to be controlled with fungicides in Finnish nurseries [47]. Although severe epidemics only occur under particular conditions [32], the potential economic loss is so great that annual application of fungicides is standard in southern and central Finland [44, 46]. Larch needlecast can be reduced by producing only 1-year-old seedlings - by meaning of Martinsson study [12].

The study of Martinsson [12] described that development of the fungus is very irregular and depends on environmental factors. The life cycle of the pathogen the commonest in central Europe has been described by Rack [10]. In damp weather during late summer and autumn ascospores spread from the needles on the ground. The spores germinate on the surface of living needles. From the beginning of August small brown infection spots can be observed. When the temperature increases in April-May, a rapid change occurs. Within a few days a whole stand of pine can change its colour from green to reddish-brown. Depending on the strength of the wind, the needles then fall off fairly rapidly. As a rule, severely affected seedlings stand completely devoid of needles for some time, until the new shoots have had time to develop new needles. The conidial stage of the fungus is developed first and can sometimes be observed before the needles are shed. After the needles have fallen, the apothecia of the fungus develop during late summer and autumn. They occur as dark elliptic spots on the surface of the needle. Later apothecia develop from the tissue of the needle into gatherings, slitting longitudinally in damp weather and discharging the spores. The fungus can also have a longer life cycle lasting for several years [8, 9, 10, 11]. The filiform ascospores have a length of 100-160 p, a width of 2-2.5 $p$ and are enclosed by a mucilaginous envelope. A variety which is slightly shorter can occur on cones [13]. The vegetatively formed conidia are smaller and rod-shaped, and, according to the same source, about $7 \times 0.7 p$. These conidial spores are unable to germinate and their significance to the fungus is unknown [14]. When the ascospores germinate on the surface of the needle, at least three different types of spores can be distinguished with regard to the cell division of the germ hyphae, the number of nuclei and growth [15]. There are relatively few stomata on one infection spot which are not penetrated by germ hyphae. On a double needle 200 individual infection spots can exist [10]. The anatomy of the fungus inside the needle has been described in detail by Jones [14]. After the fungus has penetrated the endodermis of the needle, the hyphae grow intracellularly. Since the stomata of the needle have been destroyed by the fungus, the hyphae, after having penetrated the endodermis, cause an uncontrollable transpiration of water through the hyphae of the fungus from the conducting tissue of the needle to its surface [92]. This initiates a reaction in the pine seedling, which leads to the shedding of the whole needle. The ripe apothecium is elliptic when viewed towards the surface of the needle, and has a length of 1-2 $\mathrm{mm}$ and a width of about half that size. It splits longitudinally in damp weather and closes again when the humidity level drops. According to Rack [10] each apothecium discharges about 2000 spores.

The fungus has a parasitic and a saprophytic stage. The parasitic stage constitutes the part of the life cycle in which the fungus lives on and in the live needle. The saprophytic stage 
constitutes the other part of the life cycle. The development of the apothecia is most rapid in those needles that have been shed in June-August. The development is accelerated by high humidity. The optimum temperature for an apothecia formation seems to be 13 to $14^{\circ} \mathrm{C}$, which is lower than the optimum temperature for the vegetative growth of the mycelium, which is about $18^{\circ} \mathrm{C}[10,16]$. During its saprophytic stage the fungus is highly dependent on the environmental factors influencing the moisture on the ground level. This is considered a contributory cause to the fact that the damage is especially frequent in dense plantations in grasscovered habitats and in nurseries [8]. There are also examples of stands considerably exposed to the wind being heavily attacked by Lophodermium [17]. In such cases, however, it seems to be the parasitic stage which is favourably affected. The uncontrolled transpiration in the tree is of decisive importance. Lophodermium needle cast seems able to exist on all types of forest soil and in nurseries. The physiological investigations performed have mostly been made in vitro. The fungus can be cultivated on artificial media. Growth is stimulated by the addition of pine needle extract [18]. So far nobody has been able to make fructifications with germinable spores develop on artificial media [19]. The $\mathrm{pH}$-value of the needle tissue as well as its osmotic pressure have not proved to affect the development of the fungus [20]. In different isolated cultures the optimum $\mathrm{pH}$-value for vegetative growth in Lophodermium cultures can vary between 4 and 6 . The fungus, however, will grow within the $\mathrm{pH}$-interval of 3-9 [21]. Fries and Stephan [22, 21] investigated the vitamin requirements of the fungus and found that in most Lophodermium strains the vegetative growth was favoured by biotin, thiamin and inositol. By nature the fungus is able to hydrolyze starch [21].

\subsection{The diseased pine}

High precipitation during late summer and autumn creates favourable conditions for infection [4,32]. Due to the less severe climate, southern populations of L. seditiosum are more stable and can supply infective propagules to northern latitudes [36, 32]. Climatic factors such as lower temperatures during autumn and early snow cover may explain the lower risk of needlecast in the northern part of Finland [32].

Also, in his study Martinsson [12] finds that pine seedlings with secondary needles usually survive single attacks by the pathogen. Even if all the needles have been affected and fall off in spring, the seedling is usually able to develop a new shoot with healthy needles out of the apical bud by means of the stored nutrients in the stem, branches and roots [8]. Seedlings with primary needles only, however, have less chance of surviving the attack. These small seedlings have less nutrients stored and the primary needles do not fall off as easily as do the secondary needles; thus, the fungus grows into the shoot as well. In seedlings with secondary needles the fungus does not usually have time to reach the dwarf shoot, since the needle is shed before that. This needle shedding is a defence mechanism initiated by the pathogen. The infection starts the processes that cause the needle to fall off $[23,24]$. The growth of a pine seedling depends upon the photosynthesis of the green biomass. If a large number of the needles formed during or before the preceding year are lost, root as well as stem and shoot growth is affected both directly and indirectly. The earlier during the year 
the needles are lost the more serious will be the negative influence [10]. The nitrogen and carbohydrate supply in the seedling are built up in the previous year's needles during the spring. These nutrient reserves are largest immediatly before the buds open [25], i.e. usually during the season in which the pine seedling can be deprived of its needles to a greater or lesser degree by Lophodermiurn. The number of needles on the growing shoot is predestined in the bud, which is formed as early as the year before the disease breaks out. The elongation of the shoot, however, is dependent upon the available nutrient supply and assimilated material formed in the older needles [26, 25]. If older needles are missing completely or partially, this implies a considerable loss of nutrient supply. A shorter shoot grows out, and the amount of nutrients in the roots, stem and branches is reduced. The seedling has regulating mechanisms which endeavour to adjust the proportion of the dry weight in shoots and roots to a specific value; however, this value is dependent on environmental factors [27]. If a seedling is deprived of some of its needles, thereby receiving a reduced supply of assimilated material, an unbalance arises temporarily between shoot and root. Relatively speaking, the growth of the root will suffer more from the shortage of carbohydrate than will the growth of the shoot. Due to reduced water and nutrient absorption in the root, growth of the shoot and bud is impaired. If the attack does not cease, the seedling will finally die of nutrient deficiency [28].The upper parts of a pine will be attacked less than the lower parts. The reasons may be that the infection spreads from the ground and that the microclimate higher up prevents fungus growth [10, 29]. When the pine has reached a certain height, the upper parts usually escape attack completely. A young pine stand at a height of two metres has therefore usually passed the limit below which the trees are susceptible to severe attack by Lophoderrniurn needle cast. Thus, the growth ability of the pine and, consequently, its provenance and site quality class, indirectly affect the resistance of pine to Lophoderrniurn.

\subsection{Economical significance}

When chemical disease control application is economically feasible, as in the case of Christmas trees or forest nursery stock, it is essential that the pest manager understand the life cycle of the disease to be controlled. For many diseases, only one short window of control may be available in a calendar year, or the control spray may have to be applied preventively before any signs or symptoms of disease are present. Chemical control measures must be applied to the plant when infection is most likely to occur or it will be a waste of time, effort, and money. By understanding the life cycle of the disease organism, you will be able to make proper and timely management decisions.

\subsection{The efficacy of current management strategies}

Disease surveys are important and are the first step in application of control measures. Detection, appraisal, and control surveys are made for early recognition of disease; for information on scope of attack, extent of damage, possibilities for control, estimates of costs, and delimitation of control areas; and for assessing the effectiveness of control programs. 
The major objective of disease management is to prevent or minimize losses while preserving tree quality. Absolute disease control is rarely achieved or even attempted. More often, management efforts are directed toward preventing disease or reducing it to the status of a tolerable nuisance. In most instances, forest disease management requires preventive methods over a long period of time and considers the stand as a whole rather than specific diseased individuals. Christmas tree disease management, on the other hand, is more likely to consider the value of each tree. Management measures must be economically feasible expenditures must not exceed the expected benefits. Direct control of disease in the forest is limited by many factors, including:

- The vast areas involved.

- The inaccessibility of many stands.

- The long life cycle of trees.

- The relatively low per acre or per individual tree values

Thus, spraying, dusting, or other direct control procedures commonly employed with highvalue crops such as Christmas trees, forest nursery crops, and valuable seed orchards are rarely applicable in the forest. Occasionally, however, disease epidemics of introduced forest pests warrant drastic and costly direct control measures to meet the emergency.

\section{Other Lophodermium species that seem to be involved in the disease complex}

Different periods of mass infection during a year, then different types of ascospore germination, penetration of germ tubes directly through the cuticle or through the stomata, significant anatomic-morphological differences of fruiting bodies (in particular apothecia) on primary and secondary needles, as well as numerous other ecological, biological, physiological and pathological characteristics point to the existence of a number of Lophodermium species which differ significantly [50, 42, 40, 58, 59].

Lazarev [6] had noted that Lophodermium species, as the primary pathogens, have a significant role in the succession and inter-relations with other pathogens on the needles. This is especially the case in Scots pine, which is much more susceptible to the attack of Lophodermium species than Austrian pine. By all means, the succession and connexion of other fungi is affected by weather factors. He concluded that the older primary needles of Scots pine and Austrian pine are infested by Lophodermium pinastri, and the younger ones by L. seditiosum. Based on the symptoms and the obtained isolates from region in Serbia, it can be concluded that Scots pine seedlings (primary needles) are more susceptible to the attack of Lophodermium species than Austrian pine. The same conclusion also refers to secondary needles - primary pathogens on Scots pine secondary needles are Lophodermium seditiosum, Lophodermella sulcigena and Lophodermium pinastri (on older needles), and on Austrian pine Dothistroma pini, Sphaeropsis sapinea and Lophodermium pinastri. The secondary pathogens, which occur massively on the needles diseased by primary pathogens, are the species in the genera Cyclaneusma (C. minor, C. niveus) and Cytospora friesii [60, 61, 62]. 
Lophodermium Chev. includes 145 species, mostly from pine hosts, and there is some degree of host specificity [63, 64]. Morphological characteristics of this genus include a single longitudinal slit opening of the apothecia, and the fusiform shape of the ascospores [65]. As it is known today, the Lophodermium species complex on P. sylvestris in Scotland includes two endophytes and one pathogen. The two endophytes differ in their ecology. L. pinastri ascocarps are found on naturally shed needles, while L. conigenum fruits on prematurely killed needles [54]. The pathogen L. seditiosum causes needlecast disease which is particularly a problem on young $P$. sylvestris [4].

\section{The history of fungicide usages against pine nidle cast}

Several factors must be considered before a chemical control procedure is followed. First, the type of Lophodermium must be determined. If only the older needles of the tree are affected, no control may be needed or desired. The disease on the most recently formed needles is the most destructive and usually requires fungicide applications. Second, the degree of desired control must be determined. For a high degree of control, monthly sprays throughout the year may be necessary; however, fairly good control has been achieved by monthly sprays during the late summer and fall (August to October). The fungicide label will indicate whether an additional spreader sticker is needed to give good coverage on the waxy needles [66].

Chemical control of L. seditiosum is necessary and very important in the protection of pine seedlings. It is possible to use a systemic and non-systemic fungicide from all chemical groups registered for that purpose (Table 1). In investigations of Cordell [67] we can see that two fungicides chlorothalonil and maneb are registered for control of Lophodermium needle cast. A surfactant is needed for maneb.

During the 1990s, there were serious outbreaks of the pathogen Lophodermium seditiosum on pine seedlings in Swedish forest nurseries, even though the seedlings had been treated with the fungicide propiconazole [68]. The experiment was carried out to evaluate two other fungicides, fluazinam and azoxystrobin, as possible alternatives to propiconazole. In the tests, which were all carried out in the same forest nursery, seedlings were treated with either propiconazole, fluazinam or azoxystrobin, and the proportion of needles with ascocarps of $L$. seditiosum and the number of ascocarps per needle were recorded over the following 2 yrs. Seedlings treated with azoxystrobin already appeared healthier than control seedlings in September of the first year, and by November all azoxystrobin-treated seedlings had fewer ascocarps per needle compared with control seedlings. In autumn of the second year, there were no ascocarps on seedlings treated with fluazinam or azoxystrobin, whereas seedlings treated with propiconazole had similar numbers of ascocarps to non-treated control seedlings [68]. The similar results were and in investigations of Ostry [69] with benomyl, maneb and chlortalonil.

Chemical controls have been successful in managing Lophodermium needle cast disease in nurseries and Christmas tree plantations [70, 71, 38]. However, outbreaks of this disease continue to occur periodically when control measures are not applied and where climatic 
conditions are conductive to disease development and pathogen spread. Recent outbreaks of Lophodermium needle cast were reported in the southern United States in 1986 [72] and in Michigan in 1988 [73]. In Europe, genetic differences and correlations were found for height growth of Scotch pine and severity of Lophodermium needle cast [12, 74], and young Scotch pine protection from Lophodermium infection by three fungicide applications were taller than untreated control [75]. The impact of this needle cast disease on the growth of nursery seedlings has not been documented in the Unated States. This informations is critical to advising nursery managers on how to control this pathogen.

Nicholls $[76,51]$ suggested to apply a registered, preventive fungicide such as chlorothalonil or maneb, once every 2 to 3 weeks during the major infection period from late July through October. Apply more frequently if wet weather persists. Do not grow seedlings next to red or Scotch pine windbreaks that can serve as a Lophodermium inoculum source. Plant only Lophodermium-free stock. If you suspect infection, have seedlings examined by a pest specialist.

The result of experiments on the influence of 12 fungicides such as Carbendazim, Cholrtalonil, Dithiocarbamates, Metham-sodium, Thiophanate-methyl, Bactericide (Tuzet), Benomyl etc. on conidia germination of Lophodermium pinastri (Schrad.) Cher. showed that different fungicides had distinct control effect. The fungicides screening trial demonstrated that the contorl effect of Metham-sodium, Carbendazim, Chlortalonil, Bactericide (Tuzet) on L. pinastri were better. The experiment of control of L. pinastri were carried out in the field and in the forest. The results showed spraying $45 \%$ Metham-sodium Solution could reach an efficacy of $81.2 \%$ [77].

During disease susceptible periods, apply sprays at two- to three-week intervals. See below for fungicides and application timing: Bordeaux mixture, chlorothalonil, dithiocarbamates (ferbam, or mancozeb) - Mid-July through October. [78].

Two fungicides: chlorothalonil and dithiocarbamate (maneb) are registered for control of Lophodermium needle cast. A surfactant is needed for maneb. During rain, do not apply fungicide as it tends to wash off. Spray applications are best during periods of low air movement during the still, early morning hours, for example-because these periods allow more uniform coverage. Chlortalonil is registered and effective against this disease. Use according to label directions. Nursery stock should be sprayed four times at 2-week intervals, beginning about August 1. For larger trees (2.5- 5.5m), two or tee applications of eiter chemical are suggested at 3-week intervals. Begin the treatment when temperatures remain above $26^{\circ} \mathrm{C}$, typically about mid- July, and continue until early September. Two applications should be adequate for lightly infected trees [79].

In Serbia, as well as protective measures against these diseases are given mainly preventative, such as raising nurseries away from infested pine trees from which can carry spores of these fungi. In the critical period for infection, mainly used Dithiocarbamates (Cineb a S-65 and Ortocid-50) in a concentration of $0.3 \%$, which provides almost complete 
protection against infection of new needles parasites. Number of spraying is reduced to four or five (depending on the quantity and frequency of rainfall). Usualy, the first spraying for Lophodermium controling is done around mid-June, and later as needed, ie. when rain washed out with needle tool. This means that the number of required spraying depends on the year. As a rule, should strive to do all the needles fall to be enough fungicides. It is recommended that the fungicidal soup add wetting agents, it is then easier to fine droplets of wax coating on the needles. Every annual regular spraying of pine seedlings in the nursery should be a rule in all the nurseries where the disease is observed, even if to a lesser extent, because once the disease is established, there will be wet in the first year to major damage, and then it was too late. In any case, the infected seedlings may not be transplanted, because it will be developed the disease and after transplanting, and lead to deterioration of the transplanted material. Accordingly, the spray is indispensable, because only it can ensure a sufficient quantity of healthy seedlings for afforestation.

Timing of fungicide applications may vary with geographic location and species of Lophodermium. In the Lake States and the Northeast, apply four sprays (August 1, August 15, September 1, and September 15) just before and during the period when spores are released. Where infection is severe and prolonged rainy weather is expected, spraying again on October 1 may be necessary. In the Pacific Northwest, where mild, moist conditions are expected most of the year, experience has shown that from 9 to 12 sprays are most effective. Apply year-round at approximately 1-month intervals except when beds are covered by snow [67].

When practical, diseased needles which have fallen and have piled up on branches or under trees should be raked up and destroyed. This will reduce the number of spores in the vicinity of the tree, and should help reduce the amount of future infection. Also, fungicide applications are more effective in preventing disease when the number of spores has been significantly reduced. When an affected tree is in an area where there are no other pines nearby, it is possible to keep the disease under control without fungicide application by thorough removal of dead needles from the tree and ground. The removed, dead needles should be destroyed by burning, depositing in the garbage, or in some other suitable way. Do not throw them on a compost pile or use them for mulching.

Application of chemicals to plants in order to prevent or inhibit disease development is a fundamental means of managing diseases caused by fungi. Knowledge of the effectiveness of particular compounds is important for achieving effective disease control. Equally important is an understanding of the underlying physiological mode of action of plant disease management materials.

Why is it important to know the physiological mode of action of fungicides ? It is important for resistance management and preservation of fungicide effectiveness. This meanes to incorporate fungicides with different modes of action into a disease management program as an alternation or as a mixture, to prevent the resistance of these pathogens on this fungicides. 
Fungicides - Showcases of Integrated Plant Disease Management from Around the World

\begin{tabular}{|c|c|c|c|}
\hline $\begin{array}{l}\text { FRAC } \\
\text { CODE }\end{array}$ & MODE OF ACTION & $\begin{array}{c}\text { CHEMICAL } \\
\text { FAMILY(GROUP) }\end{array}$ & ACTIVE INGREDIENTS \\
\hline 11 & Respiration & methoxyacrylates & Azoxsystrobin \\
\hline $\mathbf{M}$ & Multi-site contact activity & inorganic & Basic Copper Sulfate \\
\hline \multirow[t]{4}{*}{1} & Mitosis and cell division & benyimidazoles & benomyl \\
\hline & Multi-site contactactivity & phthalimides & Captan \\
\hline & Multi-site contact activity & $\begin{array}{l}\text { chloronitriles } \\
\text { (phthalonitriles) }\end{array}$ & Chlorthalonil \\
\hline & $\begin{array}{l}\text { Multi-site contact activity } \\
\text { Mitosis and cell division }\end{array}$ & $\begin{array}{l}\text { chloronitriles } \\
\text { (phthalonitriles) } \\
\text { thiophanates }\end{array}$ & $\begin{array}{l}\text { Chlorthalonil - } \\
\text { Thiophanate Methyl }\end{array}$ \\
\hline $\mathbf{M}$ & Multi-site contact activity & inorganic & Copper Hidroxide \\
\hline $\mathbf{M}$ & Multi-site contact activity & $\begin{array}{l}\text { Inorganic } \\
\text { dithiocarbamates }\end{array}$ & $\begin{array}{l}\text { Copper } \\
\text { Hidroxide+Mancozeb }\end{array}$ \\
\hline $\mathbf{M}$ & Multi-site contact activity & inorganic & $\begin{array}{l}\text { Copper Hidroxide+ } \\
\text { Copper Oxychloride }\end{array}$ \\
\hline \multirow[t]{2}{*}{$\mathbf{M}$} & Multi-site contact activity & inorganic & $\begin{array}{l}\text { Copper Salts of Fatty and } \\
\text { Rosin Acids }\end{array}$ \\
\hline & Multi-site contact activity & $\begin{array}{l}\text { dithiocarbamates } \\
\text { and relatives }\end{array}$ & Ferbam \\
\hline \multirow[t]{4}{*}{29} & Respiration & 2, 6-dinitro-anilines & Fluazinam \\
\hline & $\begin{array}{l}\text { NADH cytochrome c } \\
\text { reductase in lipid } \\
\text { peroxidation (proposed) }\end{array}$ & dicarboximides & Iprodione \\
\hline & Multi-site contact activity & dithiocarbamates & Mancozeb, zineb, ziram \\
\hline & $\begin{array}{l}\text { Multi-site contact activity, } \\
\text { Sterol synethesis }\end{array}$ & $\begin{array}{l}\text { Dithiocarbamates } \\
\text { triazoles }\end{array}$ & Mancozeb+Myclobutanil \\
\hline 28 & Cell membrane permeability & & propamokarb-hidrohlorid \\
\hline 3 & Sterol synethesis & triazoles & Propiconazole \\
\hline 1 & Mitosis and cell division & thiophanates & Thiophanate-methyl \\
\hline 3 & Sterol synethesis & triazoles & Triadimefon \\
\hline
\end{tabular}

Table 1. Fungicides used in the protection of Lophodermium spp. - FRAC list

However, the risk of economic losses with both bareroot and container Scots pine seedlings during an epidemic is so high that routine control with fungicides is considered to be necessary every year [44]. A lower occurrence or absence of the fungus, together with climatic factors such as lower temperatures during autumn and earlier snow cover, may explain the lower risk of needlecast $[32,56]$. In general the fungicide spraying times are 
consistent with the sporulation period of L. seditiosum [54]. In Finland spraying with fungicides such as maneb and chlorothalonil [38,51] should be carried out at 2-week intervals, from June to October [44, 12].

\section{Biological examination of efficacy of some fungicides in serbia}

\subsection{Material and methods}

\subsubsection{Experimental conditions}

Selection of crop and cultivar, test organisms - This study was established in a forest tree nursery "Barje" in Pirot, Serbia. The research was carried out on the beds of three -year-old seedlings of red pine (Pinus sylvestris). The container bed was seeded to a density of 35 seedlings per $0.3 \mathrm{~m}$. Test organism: Lophodermium seditiosum, Miller. Visual estimation of test organism was made based on the results of professor Lazarev [6] and professor Karadzic [7] for the locality of Serbia. The intensity of disease was assessed by the method of PP1/100 (2) EPPO: Guideline for the efficacy evaluation of fungicides - Lophodermium seditiosum [81]. Trial conditions - Only field trials were conducted. Trials were carried out in nurseries with 3-year-old seedlings. Homogeneous seedling lots were selected for the trials from seedling beds in nurseries where the inoculum potential of the disease was high and uniformly distributed. Design and lay-out of the trial - The trials were set in accordance with methods PP 1/152 (2) (EPPO, 1997) [80], and the treatment plan was made according to a fully randomized block design. The experiment was conducted in four repetitions. Plot size: $2 \mathrm{~m} 2$ for seedlings.

\subsubsection{Application of treatments}

Test products are: a) Blue bordo (i.e. cooper (II) sulphate pentachloride and calcium hydroxide $200 \mathrm{~g} / \mathrm{kg}$ ) used in the concentration of $0.5 \%$, b) Captan WP 50 used in the concentration of $0.3 \%$, c) Previcur $607 \mathrm{Sl}$ used in doses of $75 \mathrm{ml} / 20 \mathrm{~L} \mathrm{H} 20$. Mode of application - Applications was done with good forestry practice. Type of application and equipment - Regarding the method of application and amount of water per unit surface, the fungicides were applied using the backstroke sprayer "Solo"; with a consumption of 1000 L/ha of water. Time and frequency of application - Applications of the product were administered so as to coincide with the major spore release and infection periods, i.e. late summer and early autumn. There were 2 applications in total, administered on 21st October and 03rd November 2010. Data on chemicals used against other pests - There were no treatment with other chemicals which have to be used for other pests.

\subsubsection{Mode of assessment, recording and measurements}

Type, time and frequency of assessment - The appearance and development of flushing and dispersal of pine needles was followed by the initial appearance and development of the 
disease on the control variation, as well as through accomplishment of a clear difference between the control and other variations on which fungicides were applied. A single assessment was made after overwintering in the spring, on 21st February 2011. Each seedling was scored for percentage of needles affected. The estimation of pine needles with secondary infection was conducted by scale of values which was used to record the results of each needle, as follows: $0=$ healthy, $1=$ mild symptoms, $2=$ medium infection, less than $50 \%$ of the needles affected, $3=$ severe infection, over $50 \%$ of the needles affected. The intensity of disease was assessed by the method of EPPO: Guideline for the efficacy evaluation of fungicides - Lophodermium seditiosum, EPPO Bulletin 17, 389-394 (1987), No. 100[16]. Direct effects on the crop - The crop was examined for presence or absence of phytotoxic effects. Phytotoxicity was estimated according to instructions of PP methods (1/135 (2) [82].

\subsubsection{Statistical data}

Data processing was performed using standard statistical methods (intensity of infection according to Towsend- Heuberger [83], the efficiency according to Abbott [84], analysis of variance according to Duncan test [85] and methods PP/181 (2) [86]. The differences of the disease intensity were evaluated by the analysis of variance and LSD-test.

\subsubsection{Incubation methods}

According Sisakovic [87] for forecasting of pathogen are used incubation methods : a) The method according to Müller, b) The method according to Shatski and c) The method according to Mrezanin and Lipickaja. All of the described methods are for determining the duration of the incubation period and timing of treatment.

\subsubsection{The method according to Müller - Method 1}

On the basis of Müller's incubation curve, given with the data in Table 2, it can be inferred that the shortest duration of incubation period at the end of which is ascospores capable to erupt ascocarpes. The duration of individual incubations is determined computationally by means of a formula:

$$
\mathrm{C}=\mathrm{A} / \mathrm{B}-\mathrm{B}
$$

$\mathrm{C}=$ number of days until the end of the incubation

$A=$ sum of daily incubations starting from the day of onset of the infection until the time it ends

$\mathrm{B}=$ number of days elapsed from the day of onset of the infection until the end of the incubation (days with mean daily temperatures of $12^{\circ} \mathrm{C}$ and below are excluded).

\subsubsection{The method according to Shatski-Method 2}

The second method is based on following the incubation, using the percentage of incubation progress for relevant sums of mean daily temperatures for each day separately. 


\begin{tabular}{|c|c|c|c|c|c|c|c|c|c|c|}
\hline \multicolumn{1}{|l|}{ Temperature } \\
\hline $\mathbf{T}^{\circ} \mathbf{C}$ & 0.0 & 0.1 & 0.2 & 0.3 & 0.4 & 0.5 & 0.6 & 0.7 & 0.8 & 0.9 \\
\hline 12 & 13.0 & 12.8 & 12.5 & 12.3 & 12.0 & 11.8 & 11.6 & 11.5 & 11.2 & 11.1 \\
\hline 13 & 10.9 & 10.7 & 10.5 & 10.4 & 10.2 & 10.1 & 10.0 & 9.9 & 9.7 & 9.5 \\
\hline 14 & 9.4 & 9.3 & 9.2 & 9.0 & 8.9 & 8.8 & 8.7 & 8.7 & 8.4 & 8.3 \\
\hline 15 & 8.2 & 8.1 & 8.0 & 7.9 & 7.8 & 7.6 & 7.5 & 7.4 & 7.3 & 7.2 \\
\hline 16 & 7.1 & 7.1 & 7.0 & 6.9 & 6.8 & 6.7 & 6.6 & 6.5 & 6.5 & 6.4 \\
\hline 17 & 6.3 & 6.2 & 6.1 & 6.1 & 6.0 & 5.9 & 5.8 & 5.8 & 5.7 & 5.6 \\
\hline 18 & 5.6 & 5.5 & 5.4 & 5.4 & 5.3 & 5.3 & 5.2 & 5.1 & 5.1 & 5.0 \\
\hline 19 & 5.0 & 4.9 & 4.9 & 4.8 & 4.8 & 4.7 & 4.7 & 4.6 & 4.6 & 4.5 \\
\hline 20 & 4.5 & 4.4 & 4.3 & 4.3 & 4.3 & 4.2 & 4.2 & 4.2 & 4.2 & 4.2 \\
\hline 21 & 4.1 & 4.1 & 4.1 & 4.1 & 4.1 & 4.0 & 4.0 & 4.0 & 4.0 & 4.0 \\
\hline 22 & 4.0 & 4.0 & 4.0 & 4.0 & 4.0 & 4.0 & 4.0 & 4.0 & 4.0 & 4.0 \\
\hline 23 & 4.0 & 4.0 & 4.0 & 4.0 & 4.0 & 4.0 & 4.0 & 4.0 & 4.0 & 4.0 \\
\hline 24 & 4.0 & 4.1 & 4.1 & 4.1 & 4.1 & 4.1 & 4.2 & 4.2 & 4.2 & 4.2 \\
\hline 25 & 4.3 & 4.3 & 4.3 & 4.4 & 4.4 & 4.5 & 4.5 & 4.5 & 4.6 & 4.6 \\
\hline 26 & 4.7 & 4.7 & 4.8 & 4.8 & 4.9 & 5.0 & 5.0 & 5.0 & 5.1 & 5.2 \\
\hline 27 & 5.3 & 5.3 & 5.4 & 5.5 & 5.6 & 5.6 & 5.7 & 5.7 & 5.9 & 6.0 \\
\hline 28 & 6.1 & 6.2 & 6.3 & 6.4 & 6.6 & 6.7 & 6.9 & 7.0 & 7.2 & 7.3 \\
\hline
\end{tabular}

Table 2. Values of Müller curve for incubation period expressed in days of incubation at specified mean daily air temperatures

The percentage is calculated according to the pattern by Sisakovic [87], where the temperature of $8^{\circ} \mathrm{C}$ is taken as the lower threshold of the parasite development. The percentages are added up and the incubation is over once the sum reaches $100 \%$. Compared to the previous one, this method has certain advantages as it starts from a lower temperature threshold of development of $8^{\circ} \mathrm{C}$. The pattern comprises the following elements:

$$
\mathrm{I}=\sum(\mathrm{t}-8) / 60.100
$$

$\mathrm{I}=$ duration of the incubation period in $\%$

$\mathrm{Z}=$ sum of effective temperatures $(\mathrm{t}-8)$ per days

$\mathrm{t}=$ mean daily temperature in ${ }^{0} \mathrm{C}$

$60=$ sum of temperatures $(t-8)$ at the end of the incubation

The incubation period is over once the value I reaches $100 \%$.

Under the optimal conditions for the development of the pathogen (23-24 $\mathrm{C})$, the daily incubation is achieved with $25 \%$ and the incubation period lasts for 4 days.

The timing of treatments according to this method is similar to the one applied in the previous method, towards the very end of the incubation or once $50 \%$ of the incubation period has elapsed, depending on the possibility for administering the treatment. 


\subsubsection{The method according to Mrezanin and Lipickaja - Method 3}

The third method, Mrezanin and Lipickaja, is based on the sum of effective temperatures that amounts to $61^{\circ} \mathrm{C}$. According to these authors, forecast of the occurrence and development of the pathogen, as well as duration of the incubation period, starts from $7.9^{\circ} \mathrm{C}\left(8^{\circ} \mathrm{C}\right)$.

The sum of effective temperatures for individual mid-day temperatures is determined according to the formula

$$
I=\sum(t-8)
$$

$I=$ duration of the incubation in days

$\mathrm{Z}=$ sum of the effective temperatures $(\mathrm{t}-8)$

$8=$ minimum temperatures for growth and development of the mycelia

$\mathrm{t}=$ mean daily temperature

$\mathrm{t}-8=$ effective temperature that affects the development of the mycelia

The basis is reduction of mid-day temperatures by 8 . If the mid-day temperature is 15.3 (15.3 $-8=7.3$ ), the effective temperature is 7.3 . Once the sum of effective temperatures reaches 61 , the incubation period is over.

The timing of spray applications is determined in a similar fashion as in the previous methods, towards the end of the incubation $40-50^{\circ} \mathrm{C}$ or upon expiration of one-half of the incubation period $\left(30-35^{\circ} \mathrm{C}\right)$, if treatment cannot be completed in a single day. The advantage of this method lies in the simplicity of the calculations. It may be applied in cases of considerable temperature fluctuations, which are frequent during primary infections.

All of the described methods for determining the duration of the incubation period and timing of treatment are satisfactory and may be applied in practice.

Air humidity also impacts the duration of the incubation. If the air is saturated with moisture at the temperature of $14^{\circ} \mathrm{C}$, the incubation lasts for 6 days. At the same temperature, if the humidity is 80 and $90 \%$, the incubation lasts for 10 days, whereas at the humidity $<60 \%$, Josifovic [88] according to Schad, the mycelium in the tissue develops very slowly. This is an indication of another factor that needs to be taken into account when calculating the duration of the incubation.

The duration of the incubation may also depend on the variety of the host plant, which according to Josifovic [88] may cause the incubation to be longer or shorter by 1-2 days.

As stated above, the incubation method forecasts the application of fungicides for the purposes of protecting pine seedlings from the pathogen L. seditiosum towards the end of the incubation period. It takes into account the local climate, phenology of plant development and biology of the pathogen development.

\section{Results}

The Table 3. presents the results of intensity of infection by L. seditiosum on seedlings of red pine (\%) in Pirot, Serbia. Based on the variance analysis of the randomized block design, it 
was determined that the difference between the medians was statistically significant at the probability of $95 \%$, since F0 $>$ F0.05. Moreover, a statistically significant difference was found between mid treatments at the probability of $99 \%$, since F0>F0.01. There is no statistically significant difference between mid treatments of other variances and all untreated treatments, and the differences are incidental.

By means of a multiple comparison procedure [85], two homogenous groups were identified with statistically significant differences at $99 \%$.

As stated above, the incubation method forecasts the application of fungicides for the purposes of protecting pine seedlings from the pathogen L. seditiosum towards the end of the incubation period. It takes into account the local climate, phenology of plant development and biology of the pathogen development.

\begin{tabular}{|c|l|c|c|c|c|}
\hline No & \multicolumn{1}{|c|}{ Fungicide } & Conc. (\%) & $\begin{array}{c}\text { Infection of } \\
\text { L.seditiosum } \\
(\%)\end{array}$ & Efficacy (\%) & Standard (\%) \\
\hline 1. & Blue bordo & $0.5 \%$ & $1.61 \mathrm{a}$ & 90.87 & 99.83 \\
\hline 2. & Captan WP 50 & $0.3 \%$ & $1.58 \mathrm{a}$ & 91.03 & 100.00 \\
\hline 3. & Previcur 607 Sl & $0.3 \%$ & $1.53 \mathrm{a}$ & 91.35 & 100.36 \\
\hline 4. & Untreated & - & $17.64 \mathrm{~b}$ & 0.00 & 0.00 \\
\hline & lsd 005 & & 5.32 & & \\
\hline
\end{tabular}

Table 3. Biological efficacy on L. seditiosum on seedlings of red pine in Serbia

The level of consumption of fungicides is the result of spreading pathogen in forest production. However, often the use of pesticides in crop production are excessive and inadequate, and the costs arise because of this is unnecessary. The most important negative consequence of excessive use of pesticides are their environmental aspect, which is reflected in an increased content of residues in food and human health.

Forecasts of harmful organisms and its contribution to the rational use of pesticides are even more important. Forecast of harmful organisms is a complex process, the quality of the work requires continuous implementation of all necessary procedures. A very important role during this process belongs to the monitoring of meteorological conditions in the crop or plantation, necessary for the emergence and growth of harmful organisms. The rapid technological advances in this field of meteorology has enabled the introduction of more modern and easier monitoring devices for required meteorological elements.

In order to make an accurate determination of the incubation period according to the described methods, we followed mean daily temperatures $\left[{ }^{\circ} \mathrm{C}\right]$ and relative air humidity [\%] in the period $1^{\text {st }}$ August 2010 through 31 ${ }^{\text {st }}$ March 2011, as presented in Picture 1, in which the following cases may be distinguished: mean daily temperature above $12^{\circ} \mathrm{C}$ and relative humidity above $60 \%$; mean daily temperature below $12^{\circ} \mathrm{C}$ and relative humidity above $60 \%$; mean daily temperature above $12^{\circ} \mathrm{C}$ and relative humidity below $60 \%$; mean daily temperature below $12^{\circ} \mathrm{C}$ and relative humidity below $60 \%$ 
The most favourable conditions for the duration of the incubation are those presented under item 1 in Figure 1, i.e. the conditions with mean daily temperature above $12^{\circ} \mathrm{C}$ and relative humidity above $60 \%$.

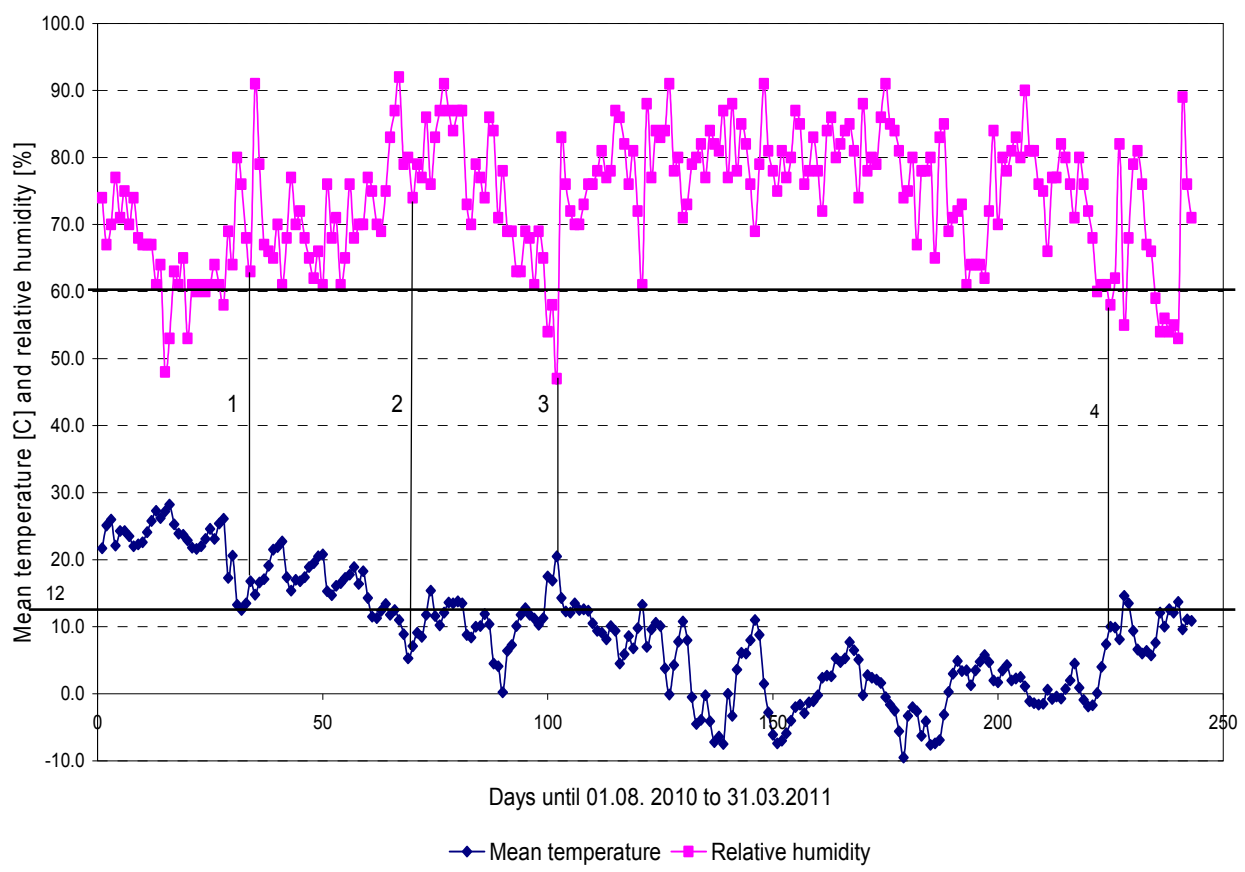

Figure 1. Mean daily temperature and relative humidity in the period 01 August 2010 through 31 March 2011

Figure 2 presents the number of consecutive days which meet both conditions and have mean daily temperatures above $12^{\circ} \mathrm{C}$ as well as relative humidity above $60 \%$, and the number of consecutive days which only meet the condition to have mean daily temperatures above $12^{\circ} \mathrm{C}$. The period during which the conditions were observed was $1^{\text {st }}$ August 2010 through 31 ${ }^{\text {st }}$ March 2011. Picture 2 shows that the most favourable conditions lasted over the first 60 days from the beginning of measuring for observation of the set conditions.

Figure 3 presents the number of days required for achieving the duration of the incubation period - METHOD 1. For example, by observing the $17^{\text {th }}$ number in the group of days we may see that the duration of the incubation period $\mathrm{I}=60$ (the blue column) while the required number of days is 11 (dark red column). In the beginning of measuring, up to the $14^{\text {th }}$ group of days, average duration of the incubation period I is approximately 55 (blue columns) while the number of required days is about 4 (dark red columns). 


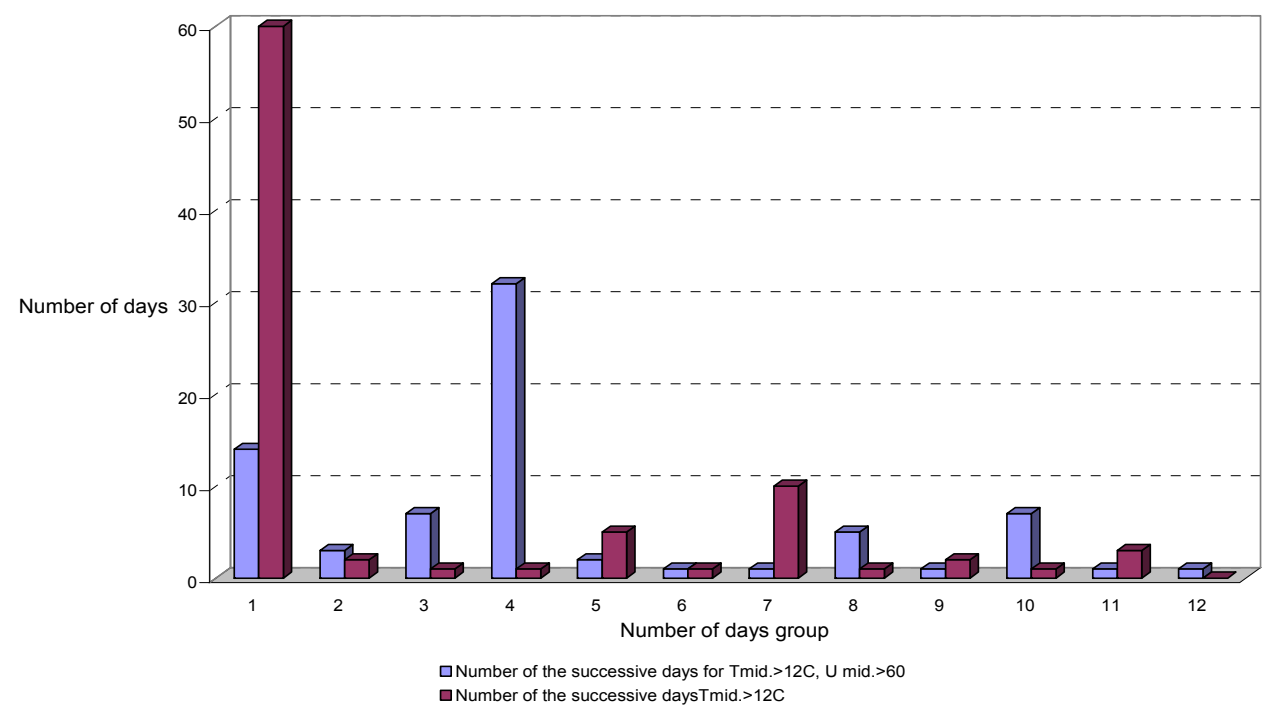

Figure 2. The number of consecutive days that provide the conditions for the formation of infection

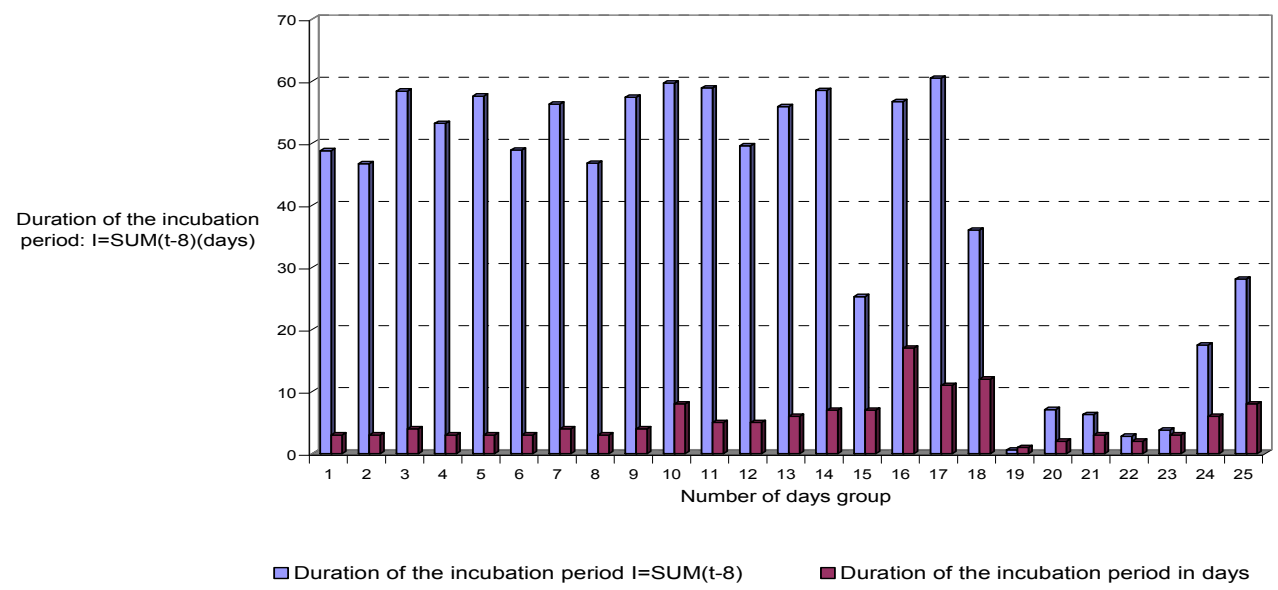

Figure 3. Duration of the incubation period $\mathrm{I}=\mathrm{SUM}(\mathrm{t}-8)$ and number of days

Figure 4 presents the days required for achieving the duration of the incubation period I given in percentages [\%] - Method 1. It may be clearly seen that there is one case in which the incubation is completed $\left(\mathrm{I}=100 \%\right.$ ), which is the $17^{\text {th }}$ measuring (number of the group of days) where the duration of the incubation period $\mathrm{I}=100 \%$, (dark red column) while the required number of days is 11 (blue column). 


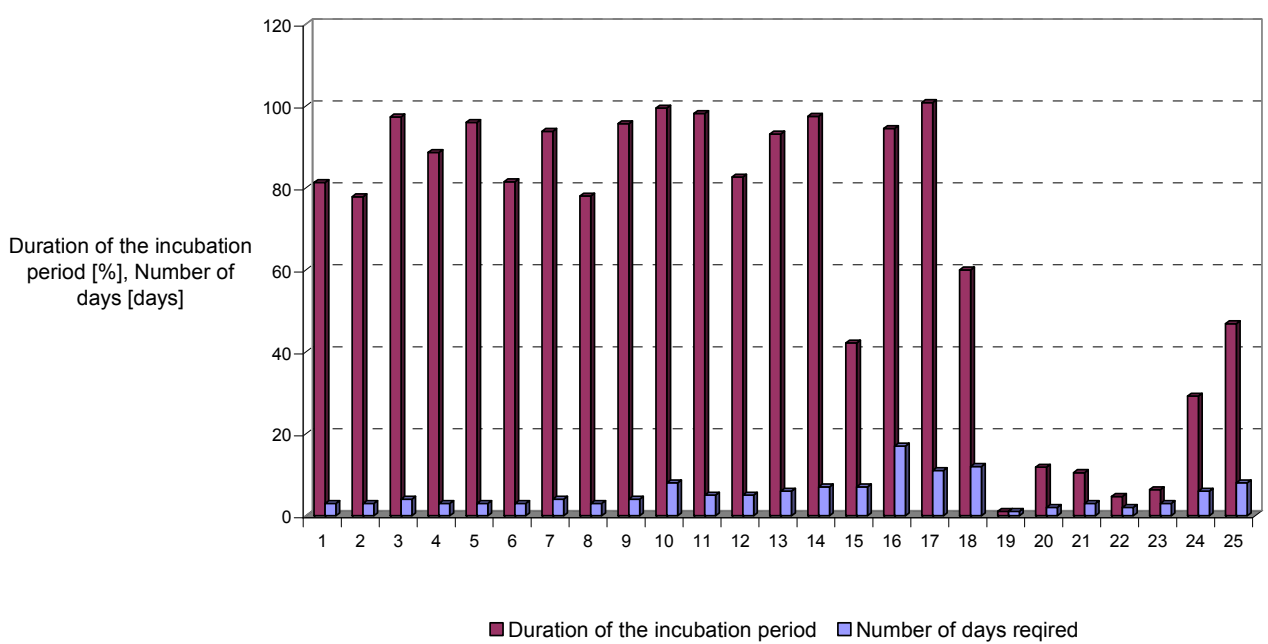

Figure 4. Duration of the incubation period $\mathrm{I}=\mathrm{SUM}(\mathrm{t}-8) / 60^{*} 100$ in [\%] and needed number of days

Figure 5 shows the number of days until the end of the incubation for the period $1^{\text {st }}$ August 2010 through $28^{\text {th }}$ August 2010 (the most favourable conditions for achieving the incubation period), Method 2. It is clear that the average value of the number of days until the end of the incubation is 10 days.

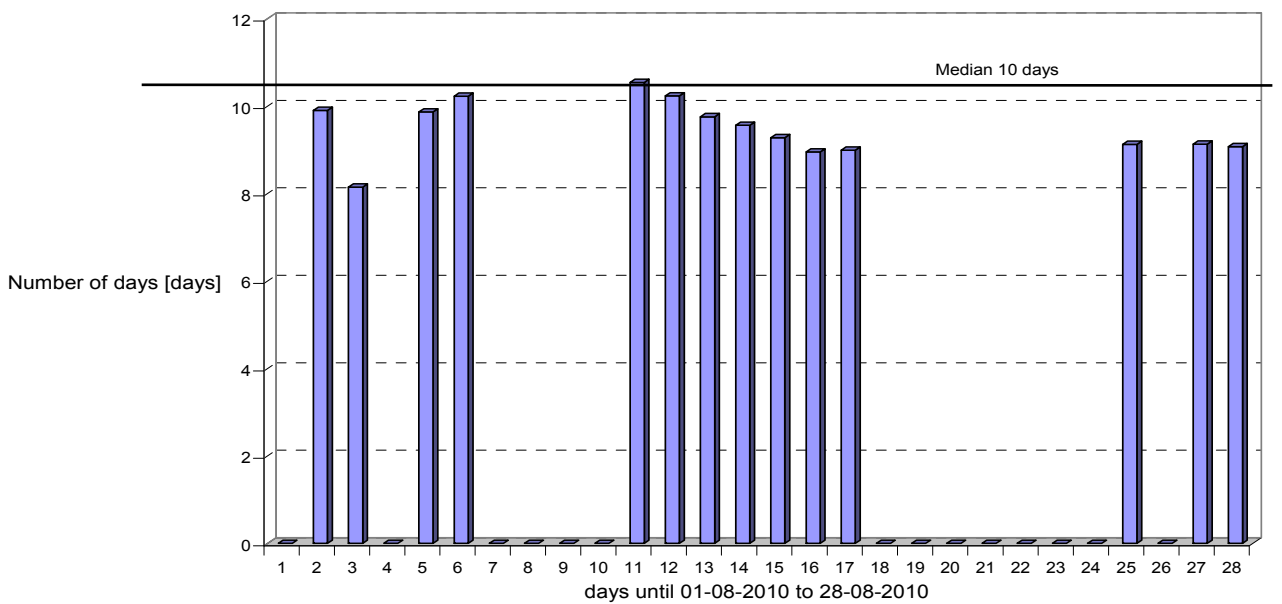

Figure 5. Number of days until the end of incubation, $\mathrm{C}=\mathrm{A} / \mathrm{B}-\mathrm{B}$

Softvrer for data calculation for Method1 and Method 2 is written in MATLAB. Thanks to this program it was possible to do the calculation for the measured data and Method 1 and Method 2, and the results were used in Microsoft Excel for graphical display of their comparative analysis. 
A comparison of Method 1 and Method 2 leads to conclusion that Method 1 is "more accurate" with the average forecast of the period of duration of the incubation about 4 days (green line on Figure 6.), while in Method 2 this period is about 10 days (blu line on Figure 6). The relative air humidity for all measurements was taken to be equal to or above 60 .

Comparison of the number of days until the end of the incubation period for Method1 and Method2

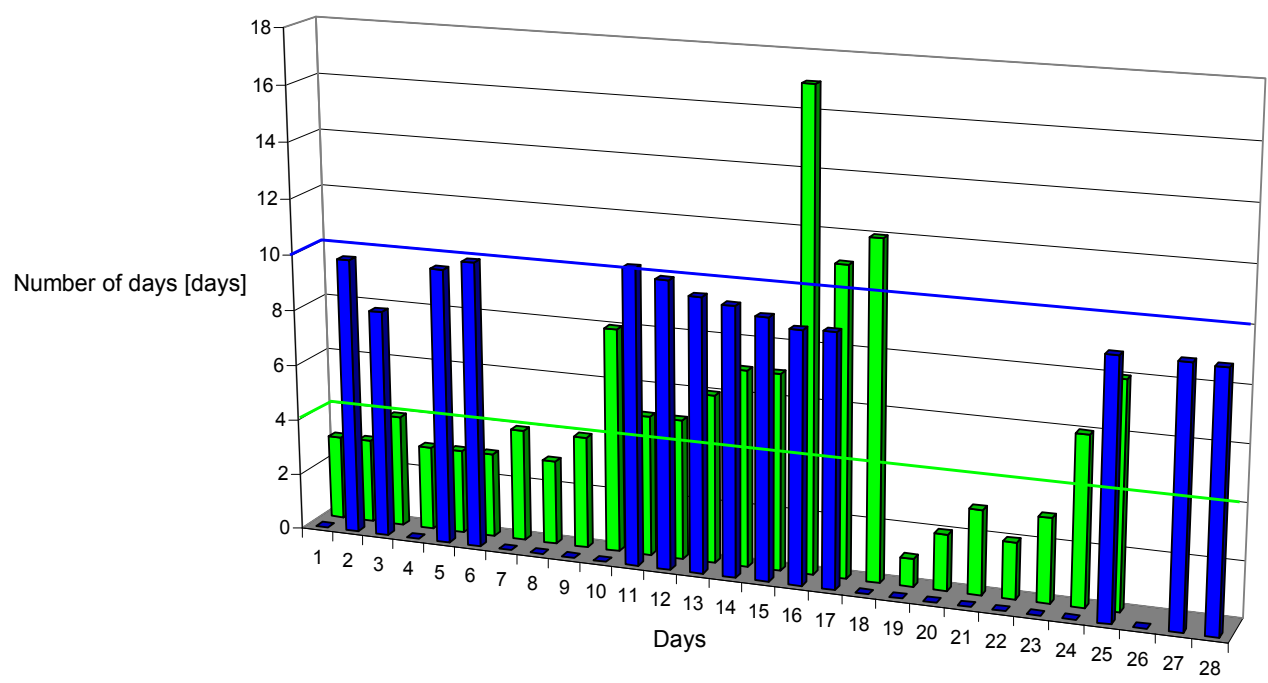

Method2 $\square$ Method1

Figure 6. Comparsion of Method 1 and Method 2

\section{Conclusion}

Species from the genus Lophodermium Chevall. is the most dangerous and the most harmful pathogenic fungus in nurseries and young crops, which causes redness and dispersal of pine needles.

Forecast of harmful organisms is a complex process, the quality of the work requires continuous and thorough implementation of all necessary procedures. A very important role during this process belongs to the monitoring of meteorological conditions in the crop or plantation, necessary for the emergence and growth of harmful organisms. The rapid technological advances in this field of meteorology has enabled the introduction of more modern and easier monitoring devices required meteorological elements. 
In order to use pesticides to rationalize and optimize, the proposed prognostic models were predict the development of this disease. In this way the forecasting models allow producers the timely and successful intervention in order to prevent damage of the causal disease.

Preventive as weel as cultural and chemical controls have been developed to minimase damage.

\section{Author details}

Snezana Rajkovic *

Laboratory for Testing, Institute for Forestry, Belgrade, Serbia

Miroslava Markovic

Plant Protection Department, Institute for Forestry, Belgrade, Serbia

Ljubinko Rakonjac

General Manager, Institute for Forestry, Belgrade, Serbia

\section{Acknowledgement}

The study was carried out within the Project TP 31070: “The development of technological methods in forestry in order to attain optimal forest cover", financed by the Ministry of Education and Science of the Republic of Serbia.

\section{References}

[1] Lazarev V (1980) Bioecological characteristics of Lophodermium spp. on Scots pine and the nurseries of Bosnia. Current research on conifer needle diseases. IUFRO Working Party on needle diseases, 59-67.

[2] Lazarev V (2005) Forest Phytopathology, University of Banja Luka, Faculty of Forestry. Banja Luka: 1-595

[3] Minter DW, Staley JM, Millar CS (1978) Four species of Lophodermium on Pinus sylvestis. Trans. Br. Mycol. Soc. 71: 295-301

[4] Diwani SA, Millar CS (1987) Pathogenicity of three Lophodermium species on Pinus sylvestris L. Eur. Journ. Forest Pathol. 17: 53-58

[5] Karadzic D, Andjelic M (2002) The most common fungi agents of wood decay in forest and wood storages, Monograph, Center for the Protection and Promotion of the forest of Montenegro - Podgorica. 1-154

[6] Lazarev V, Karadzic D, Markovic M, Pap P, Poljakovic-Pajnik L (2007) The Most Frequent Lophodermium spp. on Scots Pine and Austrian Pine and Their Role in the Appearance of Other Fungi on the Needles. Acta Silv. Lign. Hung., Spec. Edition (2007) 53-59

\footnotetext{
${ }^{*}$ Corresponding Author
} 
[7] Karadzic D (2010) Forest Phytopathology. University of Belgrade, Faculty of Forestry, Planet Print: 1-774

[8] Lagerberg T (1913) En abnorm barrfallning hostallen. - Medd. Stat. skogsforskningsinst.10

[9] Hagem O (1926) Schiitteskader paa Furuen (Pinus sylvestris). - Medd. Vestl. Forstl. Forsoksstation 7.

[10] Rack K (1963) Studies on needle-cast of Scots pine I-III. 2. Pfl. Krankheiten. $70(3 ; 5 ; 7)$ 137-146; 257-272; 385-398

[11] Shevchenko SV (1968) Needle shedding- Schiitte-a dangerous disease of Pine stands in the Western Region of the Ukrainian SSR. - Ukrainskyj botanickyj zurnal XVIII (5).

[12] Martinsson O (1979) Testing Scots pine for resistance to Lophodermium needle cast. Stud. For. Suec. 150: 63

[13] Butin H (1975) Beitrag zur Ascomyzetenflora von Chile. Sydowia 27: 267-292

[14] Jones SG (1935) The structure of Lophodermium pinastri (Schrad.) Chev. - Ann. Bot. 49.

[15] Stephan BR (1969) Karyologische Untersuchungen an keimenden Ascosporen und Hyphenzellen von Lophodermium pinastri (Schrad.) Chev. - Arch. Mikrobiol. 67.

[16] Schiitt P (1967) Experimentelle Ergebnisse bei Laborinfektionen von Kiefern mit Lophodermium pinustri (Schrad.). - Forstw. C. bl. 86.

[17] Hagem O (1928) Lophodermium-Schiitte in West-Norwegen. - Z. Pfl Krankh. Pfl Schutz 38 (718)

[18] Schiitt P (1964) Eine mykologische Methode der Resistenzprufung entwickelt fur den Lophodermium - Befall der Kiefer. - Phytopath. z. 51.

[19] Melchior GH (1975) Research in Resistance in Pinus sylvestris to Lophodermium pinastri in the Institute of Forest Genetics and Forest Tree Breeding of the Federal Research Organisation of Forestry and Forest Products. - Mitt. Bundesf. Forst u. Holzw. 108.

[20] Hattemer H (1964) Die Reaktion der osmotische Wert des Nadelzellsafts von Kiefern (Pinus sylyvestris L.) verschiedener geografische Herkunft im Zusammenhann mit deren Anfalligkeit gegen die Schiitte (Lophodermium pinastri (Schrad.) Chev.). - Mitt. Bundesf. Forst. u. Holzw. 56.

[21] Stephan BR (1973) Untersuchungen zur Variabilitat von Lophodermium pinastri. I. Kulturversuche. Eur. J. For. Path. 3. 11. Unterschiede im physiologischen Verhalten. Eur. J. For. Path. 3.

[22] Fries N (1938) Uber die Bedeutung von Wuchstoffen fur das Wachstum verschiedener Pilze. - Sym. Bot. Upsal. 111: 2.

[23] Tubeuf CV (1913) Schiittekrankheit der Kiefer. - Naturw. Z. Land u. Forstw. 11(8)

[24] Langner W (1933) Uber die Schutteltrankheit der Kiefernadeln Pinus strobus und Pinus sylvestris. Phytopath. Z. 5.

[25] Kreuger KW (1967) Nitrogen, Phosphorous and Carbohydrates in expanding year old Douglas-fir Shoots. - Forest Sci. 13.4. 
[26] Neish AC (1958) Seasonal changes in metabolism of spruce leaves. - Can. J. Bot. 36.

[27] Waering PF (1970) Growth and its Co-ordination in Trees. - Sec. Long Ashton Symp. 1969, Phys. of Tree Crops.

[28] Lyr H, Hoffman G (1967) Growth rates and growth periodicity of the roots. - Int. Rev. For. Res. Bd. 2.

[29] Blair RL (1970) Quantitative inheritance of resistance to Fusiform rust in Loblolly pine. Diss., N.C. State Univ.

[30] Diwani SA, Millar CS (1981) Biology of Lophodermium seditiosum in nurseries in N.E. Scotland. p 67-74

[31] Martinsson O (1975) Lophodermium pinastri (needle cast) - An outline of the problem in Sweden. In: Stephan, B. R. \& Millar, C. S. (eds.). Lophodermium an Kiefern. Mitteilungen der Bundesforschungsanstalt fur Forst- und Holzwirtschaft 108. p. 131135.

[32] Kurkela T (1979) Association of Lophodermium seditiosum Minter et ala needle cast epidemics on Scots pine (Pinus sylvestris). Folia For. Helsinki, 393, p 11

[33] Sieber TN (1988) Endophytische Pilze in Nadeln von gesunden und geschädige Fichten (Picea abies (L.) Karsten. European Journal of Forest Pathology 18: 321-342

[34] Müller MM, Hallaksela AM (1998) A chemotaxonomical method based on FASTprofiles for the determination of phenotypic diversity of spruce needle endophytic fungi. Mycological Research 102: 1190-1197

[35] Diwani SA, Millar CS (1990) Sources of inoculum of Lophodermium seditiosum on Pinus sylvestris. European Journal of Forest Pathology, 20: 1-7

[36] Hanso M (1968) Phenological observations of saporulation and dissemination of microfungi in pine forests. Transactions of the Estonian Agricultural University, 50: 194209 [In Estonian, summary in English and Russian]

[37] Uscuplic M (1981) Infekcioni period Lophodermium seditiosum Min., Stal. and Mill, i mogucnosti njegovog suzbijanja $u$ rasadnicima. Summary: The infection period of Lophodermium seditiosum Min., Stal. and Mill, and the possibility of its control in nurseries. Zastita Bilja 32(4): 375-382

[38] Nicholls TH, Skilling DD (1974) Control of Lophodermium needlecast disease in nurseries and Christmas tree plantations. USDA Forest Service, Research Paper NC-110. $11 \mathrm{p}$

[39] Lazarev V (1981a) Intezitet napada Lophodermium vrsta i razvoj bolesti na klijancama domacih provenijencija bijelog bora. Summary: Intensity of the attack of Lophodermium species and the development of the disease on some Yugoslav provenances of Scots pine seedlings. Zastita Bilja 32(1): 91 - 99

[40] Minter DW (1981a) Lophodermium on pines. CMI Mycological Papers 147: 1-54

[41] Minter DW (1981b) Possible biological control of Lophodermium seditiosum. In: Millar, C. S. (ed.). Current research on conifer needle diseases. Proceedings of IUFRO WP on Needle Diseases, Sarajevo, 1980. Aberdeen University Forest Department, Old Aberdeen, p. 75-80. 
[42] Staley JM (1975) The development on, and penetrationinto Pinus sylvestris foliage, of a pathogenic Lophodermium. Mitteilungen der Bundesforschungsanstalt, fiir Forst- und Holzwirtschaft 108. p 43

[43] Savkina EV (1989) Photosyntetic activity of pine seedlings infected with the fungus Lophodermium seditiosum and the nematode Pratylencus teres. Trudy Gel'mintogicheskoi Laboratorii 1989(37): 137-140

[44] Lilja S (1986) Diseases and pest problems on Pinus sylvestris nurseries in Finland. Bulletin OEPP/EPPO Bulletin 16: 561-564

[45] Stenström E, Ihrmark K (2005) Identification of Lophodermium seditiosum and L. pinastri in Swedish forest nurseries using species-specific PCR primers from the ribosomal ITS region. Forest pathology, vol. 35 (3): 163-172

[46] Poteri M (2008) Taimituho-opas. Metsäntutkimuslaitos, Suonenjoen toimintayksikkö. 155 p. [In Finnish]

[47] Jamalainen EA (1956) Männyn karisteen torjunta kemiallisilla aineilla Leksvallin taimitarhassa. Summary: The control of the needle cast of pine with chemicals at the Leksvall nursery. Silva Fennica 88(2): 1-10.

[48] Peace T R (1962) Pathology of trees and shrubs. Clarendon Press, Oxford, p. 299302

[49] Costonis AC (1970) Acute foliar injury of eastern white pine induced by sulfur dioxide and ozone. Phytopathology 60: 994-999

[50] Millar CS, Watson AR (1971) Two biotypes of Lophodermium pinastri in Scotland. European Journal of Forest Pathology 1: 87-93

[51] Ostry ME, Nicholls TH (1989) Effects of Lophodermium seditiosum on growth of pine nursery seedlings in Wisconsin. Plant Disease 73: 798- 800

[52] Lazarev V (1983Needle diseases of Scots pine (Pinus sylvestris L.). Plant Protection 34(2): 265-274

[53] Karadzic D (1989) Mechanism of infection of some fungi on Austrian and Scots pine needles. Plant Protection 40(1): 35

[54] Minter DW, Millar CS (1980) Ecology and biology of three Lophodermium species on secondary needles of Pinus sylvestris. European Journal of Forest Pathology, 10, 169181

[55] Fystro I (1961) Control of L. pinastri by spraying in the nursery. Tidsskr. Skogbr. 69, 157175

[56] Kurkela (1994) Metsän taudit. Otatieto Oy, Tampere. p 320 [In Finnish]

[57] Hanso M (1963) Aus der Biologie des Erregers der Kiefernschütte Lophodermium pinastri Chev. In der Estnischen SSR. Transactions of the Estonian Agricultural University, 33: 130-142 [In Estonian, summary in German and Russian]

[58] Lazarev V (1980) Bioecological characteristics of Lophodermium spp. on Scots pine and the nurseries of Bosnia. Current research on conifer needle diseases. Sarajevo, IUFRO Working Party on needle diseases, 59-67 
[59] Lazarev V (2004) Variability of Lophodermium species on pines. Belgrade, Faculty of Forestry, 89: 7-40

[60] Petrini O (1991) Fungal endophytes of tree leaves. Microbial ecology of leaves, 179197

[61] Arnold AE, Mejia LC, Kyllo D, Rojas EI, Maynard Z, Robbins N et al (2003) Fungal endophytes limit pathogen damage in a tropical tree. Proceedings of the National Academy of Science of the United States of America, 100, 1564915654

[62] Wilson D (1995) Endophyte: The Evolution of a Term, and Clarification of Its Use and Definition. Oikos, 73, 274-276

[63] Kirk PM, Cannon FP, Minter WD, Stalpers AJ (2008) Dictionary of the Fungi 10th Edition (10th ed. CABI Publishing.)

[64] Ortiz-Garcia S, Gernandt DS, Stone JK, Johnston PR, Chapela IH, Salas-Lizana R et al (2003) Phylogenetics of Lophodermium from pine. Mycologia, 95, 846-859

[65] Darker GD (1967) A revision of the genera of the Hypodermataceae, 45, 1399-144

[66] Ormrod DJ (1976) Control of Lophodermium needle cast of Scots pine Christmas trees in British Columbia. Can. Plant. Dis. Surv. 56: 69-72

[67] Cordell CE, Anderson RL, Hoffard WH, Landis TD, Smith RS Jr, Toko HV (1989) Forest Nursery Pests. USDA Forest Service, Agriculture Handbook No. 680, 184 pp

[68] Stenström E, Arvidsson, B (2001) Fungicidal control of Lophodermium seditiosum on Pinus sylvestris seedlings in Swedish forest nurseries. Scandinavian Journal of Forest Research, 16: $147-154$

[69] Ostry M (1989) A guide to insect, disease, and animal pests of poplar. Washington: United States Department of Agriculture - Forest Service, Agriculture Handbook 1677

[70] Nicholls TH, Skilling DD (1970) Lophodermium pinastri outbreak in Lake States forest nurseries. Plant Dis. Rep. 54: 731-733

[71] Nicholls TH (1973) Fungicide control of Lophodermium pinastri on red pine nursery seedlings. Plant Dis. Rep. 57: 263-266

[72] Hofacker TH, Loomis RC, Tucker TM (1987) Testing Scots pine for resistance to Lophodermium needle cast. Stud. For. Suec. 150. pp 63

[73] Addams GC, Roberts DL (1988) Epidemics of Lophodermium needle cast of Scotch pine in Michigan. Plant Disease 72: 801

[74] Squillace AE, La Bastide, van Vredenburch (1975) Genetic variation and Breeding of Scots pine in the Netherlands. - For. Sci. 21.

[75] Pagony H (1970) The effect of Lophodermium pinastri attack on the early growth of Scots pine plantations. Erdeszeti Kut. 66: 119-125

[76] Nicholls TH, Brown DH (1975) How to identity Lophodermium and brown spot diseases on pine. St. Paul, MN: U.S. Department of Agriculture, Forest Service, North Central Forest Experiment Station. p 5 
[77] Huang JW, Kuhlman EG (1990) Fungi associated with damping-off of Slash pine seedlings in Georgia. Plant Disease 74: 27-30

[78] A Van Maanen, F. Gourbière (2000) Balance between colonization and fructification in fungal dynamics control: a case study of Lophodermium pinastri on Pinus sylvestris needles. Mycological Research 104, Issue 05: pp 587-594

[79] Heimann MF, Stanosz GR, Worf GL (1997) Pine needle diseases: Brown spot and Lophodermium needlecast. University of Wisconsin. web site cecommerce.uwex.edu.

[80] EPPO (1997): Guidelines for the efficacy evaluation of plant protection products: Design and analysis of efficacy evaluation trials - PP 1/152(2), in EPPO Standards: Guidelines for the efficacy evaluation of plant protection products, 1, EPPO, Paris: 37-51

[81] EPPO (1997). Guideline for the efficacy evaluation of fungicides- Lophodermium seditiosum, No. PP 1/100 (2) in Guideline for the efficacy evaluation of Plant Protection Products. 2: 30-35.

[82] EPPO (1997): Guidelines for the efficacy evaluation of plant protection products: Phytotoxicity assessment - PP 1/135(2), in EPPO Standards: Guidelines for the efficacy evaluation of plant protection products, 1, EPPO, Paris, 31-36

[83] Towsend GR, Heuberger JW (1943) Methods for estimating losses by diseases in fungicide experiments. Plant Dis. Rep., 24: 340-343

[84] Abbott WS (1925) A method for computing the effectiveness of an insecticide. J Econ Entomol. 18:265-267

[85] Duncan DB (1955) Multiple-range and multiple F test. Biometrics, 11, pp 1-42

[86] EPPO (1997) Guidelines for the efficacy evaluation of plant protection products: Conduct and reporting of efficacy evaluation trials - PP 1/181(2), in EPPO Standards: Guidelines for the efficacy evaluation of plant protection products, 1, EPPO, Paris, 52-58

[87] Sisakovic V (1983) Principles of forecasting and reporting services to protect crop plants, the Union of Plant Protection Society of Yugoslavia. 612-623.

[88] Josifovic M (1964) Agricultural Phytopathology, Scientific Book, Belgrade :1-573

[89] Zgela M (1999) The production of forest seeds in seed orchards. Manuscript. Forestry Institute Jastrebarsko 34 (1): 103-121

[90] Gwaze D, Hoss G, Biram D(2007) Shortleaf pine seedling production and seeding trends in Missouri. In: Kabrick, John M, Dey DC, Gwaze D eds. Shortleaf pine restoration and ecology in the Ozarks: proceedings of a symposium; 2006, November 7-9; Springfield, MO. Gen. Tech. Rep. NRS-P-15. Newtown Square, PA: U.S. Department of Agriculture, Forest Service, Northern Research Station: 147152

[91] Cain MD, Shelton MG (2001) Twenty years of natural loblolly and shortleaf pine seed production on the Crossett Experimental Forest in southeastern Arkansas. Southern Journal of Applied Forestry. 25(1): 40-45 
[92] Owe M(1979) Testing Scots Pine for Resistance to Lophodermium Needle Cast. Studha Fbrestalia Suecica. 150:7-10. 